Research Paper

\title{
Effects of the fungicides azoxystrobin, pyraclostrobin and boscalid on the physiology of Japanese cucumber
}

\author{
Amanda Cristina Esteves Amaro ${ }^{\mathrm{a}, *}$, Anamaria Ribeiro Pereira Ramos ${ }^{\mathrm{a}}$, Ana Claudia Macedo ${ }^{\mathrm{a}}$, \\ Elizabeth Orika Ono ${ }^{\mathrm{b}}$, João Domingos Rodrigues ${ }^{\mathrm{b}}$ \\ a Faculdade de Ciências Agronômicas (FCA), Universidade Estadual Paulista “Júlio de Mesquita Fulho" (UNESP), Campus de Botucatu, Departamento de Horticultura, CP- \\ 237, 18603-970, Botucatu, SP, Brazil \\ b Instituto de Biociências (IB), Universidade Estadual Paulista “Júlio de Mesquita Filho" (UNESP), Campus de Botucatu, Departamento de Botânica, CP-510, 18618-970, \\ Botucatu, SP, Brazil
}

\section{A R T I C L E I N F O}

\section{Keywords:}

Carboxamides

Cucumis sativus L.

Physiological effects

Strobilurin

\begin{abstract}
A B S T R A C T
Strobilurins are fungicides with beneficial physiological effects on crop yield due to promotion of net carbon assimilation, nitrate reductase enzyme activity, stress tolerance and hormonal balance. The carboxamides complement the action of the strobilurins when applied alternately or together. This study aimed to evaluate the effect of application of pyraclostrobin, azoxystrobin and boscalid on grafted and ungrafted Japanese cucumber (Cucumis sativus L.) in order to analyze the effects of these fungicides on plant physiology and increased fruit production. The experimental design was completely randomized in a $2 \times 5$ factorial scheme, with grafted and ungrafted cucumber plants and 5 fungicide treatments: control; azoxystrobin $60 \mathrm{~g}$ a.i ha ${ }^{-1}$; boscalid $50 \mathrm{~g}$ a.i $\mathrm{ha}^{-1}$; pyraclostrobin $50 \mathrm{~g}$ a.i ha ${ }^{-1}$; and boscalid $100 \mathrm{~g}$ a.i ha ${ }^{-1}+$ pyraclostrobin $50 \mathrm{~g} \mathrm{a.i} \mathrm{ha}^{-1}$, applied 18 days after transplanting and then at intervals of seven days. The effect of the treatments was evaluated based on the average yield and fruit mass, in addition to observations of gas exchange, lipid peroxidation, and the activities of peroxidase, superoxide dismutase, catalase and nitrate reductase. Based on the results obtained, it was concluded that the fungicide treatments resulted in different responses between the grafted and ungrafted plants. The physiological benefits were more evident in the grafted plants treated with pyraclostrobin or boscalid alone, and these benefits manifested in terms of fruit production and increased the activity of the antioxidative system, thereby reducing stress. The higher productivity probably occurred due to the better physiological performance of these plants, mainly at the beginning of development, presenting greater activity of the enzyme nitrate reductase, in addition to the higher net $\mathrm{CO}_{2}$ assimilation and carboxylation efficiency.
\end{abstract}

\section{Introduction}

Until recently, disease control was the only purpose of fungicide use; however, the physiological benefits of strobilurins opened a new concept for the use of these products (Venancio et al., 2003). Due to the large capacity of the plant to absorb them, these fungicides have positive physiological effects on the yields of crops, causing alterations in metabolism and growth (Koehle et al., 2002). This effect was observed even without any alterations caused by pathogenic fungi; the plants treated with these substances showed greater vigor and higher yield than untreated plants. The carboxamides have also been included in this group of fungicides with positive physiological effects, but because they have spent less time on the market, there is little information or experimental results regarding this family.
The physiological effect of strobilurins results from the net photosynthesis increase due to the temporary reduction of plant respiration, which causes less carbon loss, thereby generating more energy for the plant. In addition, strobilurins increase the activity of nitrate reductase and antioxidant enzymes, which leads to greater stress tolerance; additionally, increased synthesis of indoleacetic acid (IAA), isopentenyl adenine (I6-ADE) and abscisic acid (ABA) and reduced ethylene production leads to a better hormonal balance, delayed senescence and prolonged photosynthetic activity, the so-called "green effect" (Bartlett et al., 2002; Ypema and Gold, 1999; Zhang et al., 2010).

Most of the results in the literature have been obtained in experiments on field crops, such as soybean (Fagan et al., 2010; Joshi et al., 2014; Soares et al., 2011), corn (Barbosa et al., 2011; Blandino et al., 2012), wheat (Grossmann and Retzlaff, 1997; Inagaki et al., 2009;

\footnotetext{
* Corresponding author.

E-mail addresses: amandaceamaro@gmail.com (A.C.E. Amaro), anamaria-ramos@oi.com.br (A.R.P. Ramos), anamacedo85@gmail.com (A.C. Macedo), eoono@ibb.unesp.br (E.O. Ono), mingo@ibb.unesp.br (J.D. Rodrigues).
} 
Ishikawa et al., 2012; Koehle et al., 2002; Ypema and Gold, 1999), bean (Jadoski et al., 2015; Kozlowski et al., 2009) and barley (Jabs et al., 2002), and there are few reports on the physiological effects of these fungicides on vegetables, although they are also used preventively in this group, mainly in the Solanaceae and Cucurbitaceae families. Studies on the physiological changes in the plant are scarce, there is much controversy on this subject, and there few data on the effects on diseasefree plants.

The Japanese cucumber (Cucumis sativus L.) is among the crops that are most widely cultivated in a protected environment. The use of this technique allows year-round production of fruits with excellent commercial quality, reducing losses and increasing productivity (Mohammadi and Omid, 2010). However, this practice causes problems such as increased incidence of diseases and nematodes, requiring the use of grafting in resistant plants for preventive purposes to control diseases and improve the absorption of nutrients (Lee and Oda, 2010).

Agricultural practices aim to increase productivity and the quality of the final product, so it is increasingly important to understand the physiological changes that occur after the application of these important groups of fungicides. The aim of this study was to evaluate the effect of the application of pyraclostrobin, azoxystrobin and boscalid on grafted and ungrafted Japanese cucumber plants in order to analyze the effects of these fungicides on plant physiology, as well as on the increase of fruit production.

\section{Material and methods}

\subsection{Plant material and application of fungicides}

The experimental area was located at the Faculdade de Ciências Agronômicas (FCA), Universidade Estadual Paulista (UNESP), located in São Manuel city, São Paulo state, Brazil. The study site is located at $22^{\circ} 44^{\prime} \mathrm{S}$ latitude, $47^{\circ} 34^{\prime} \mathrm{W}$ longitude, and an altitude of $750 \mathrm{~m}$. The climate is humid subtropical mesothermic with drought conditions in the winter season. We used an arc-type greenhouse with the following characteristics: $30 \mathrm{~m}$ length, $7 \mathrm{~m}$ width and $3 \mathrm{~m}$ height, covered with low-density polyethylene film $(150 \mu \mathrm{m})$ with the lateral sides covered with a $75 \%$ shade cloth.

The experiment was conducted with grafted and ungrafted Japanese cucumber plants (Cucumis sativus L.). The Japanese cucumber hybrid 'Taisho' (scion) was grafted onto the pumpkin hybrid 'Excitte Ikki' (root-stock) using the tongue approach grafting method. To ensure that both hypocotyl diameters were similar, allowing proper grafting, the pumpkins were sown 4 days before the cucumbers. The grafting was performed 10 days after sowing the cucumbers, and the plants were transplanted into pots 4 days after grafting. Thereafter, the seedlings were kept in a moist chamber until they were suitable for transplantation.

A spacing of $1.0 \times 0.5 \mathrm{~m}$ was used between seedlings. The seedlings were guided conducted with one stem oriented vertically to avoid damage to fruit production or quality. We removed all shoots and eliminated all buds and flowers from the 1 st node through the 5th node, allowing the side branches to grow starting from the 6th node; the side branches were topped and tailed after the 3rd internode.

The experimental design was completely randomized in a $2 \times 5$ factorial scheme, with grafted and ungrafted cucumber plants and 5 treatments with fungicides: control; azoxystrobin $60 \mathrm{~g}$ a.i ha ${ }^{-1}$; boscalid $50 \mathrm{~g}$ a.i ha ${ }^{-1}$; pyraclostrobin $50 \mathrm{~g}$ a.i ha ${ }^{-1}$; and boscalid $100 \mathrm{~g}$ a.i $\mathrm{ha}^{-1}+$ pyraclostrobin $50 \mathrm{~g}$ a.i ha ${ }^{-1}$, applied 18 days after transplanting and then at intervals of seven days.

The azoxystrobin source (strobilurin) was the product Amistar containing $500 \mathrm{~g} \mathrm{~kg}^{-1}$ a.i.; for boscalid, the product was Cantus ${ }^{\circ}$, containing $500 \mathrm{~g} \mathrm{~kg}^{-1}$ a.i.; for pyraclostrobin (strobilurin), the product used was Comet, containing $250 \mathrm{~g} \mathrm{~L}^{-1}$ i.a.; and for the mixture of boscalid and pyraclostrobin, the product used was Bellis ${ }^{\circ}$, containing $200 \mathrm{~g} \mathrm{~kg}^{-1}$ boscalid and $100 \mathrm{~g} \mathrm{~kg}^{-1}$ pyraclostrobin.
The fungicide applications were carried out via foliar spraying using a manual pressurized $\mathrm{CO}_{2}$ sprayer with $0.3 \mathrm{~kg} \mathrm{fm}^{-2}$ with conical nozzles and using a plastic curtain between treatments to avoid drift. Healthy plants were used so that only the physiological effect, rather than the antifungal effect, could be observed.

The first application of the treatments was carried out 18 days after transplanting (DAT), when the seedlings had 6 completely expanded leaves, and subsequent applications were at seven days intervals, with four replicates and six plants per plot, assuming four useful plants.

Physiological and biochemical evaluations were performed at the beginning of the harvest (35 DAT), the peak of the harvest (57 DAT) and the end of the harvest (80 DAT); at each time point, the second fully expanded leaf that was healthy and without signs of senescence was selected and standardized.

\subsection{Gas exchange}

Gas exchange was measured with an infrared $\mathrm{CO}_{2}$ and water vapor analyzer (LI-6400, Li-Cor Inc., Lincoln NE, USA). The measurements were performed from 9:00 am until 11:00 am on a sunny day. The net assimilation rate $\left(A_{\text {net }}, \mu \mathrm{mol} \mathrm{CO} \mathrm{CO}_{2} \mathrm{~m}^{-2} \mathrm{~s}^{-1}\right)$, transpiration (E, mmol $\left.\mathrm{H}_{2} \mathrm{O} \mathrm{m}^{-2} \mathrm{~s}^{-1}\right)$ and stomatal conductance $\left(g_{\mathrm{s}}, \mathrm{mol} \mathrm{H}_{2} \mathrm{O} \mathrm{m}^{-2} \mathrm{~s}^{-1}\right)$ were measured. The water use efficiency (WUE, $\mu \mathrm{mol} \mathrm{CO}_{2}$ (mmol $\left.\mathrm{H}_{2} \mathrm{O}\right)^{-1}$ ) was determined by the relationship between net assimilation rate and transpiration, and the apparent carboxylation efficiency ( $A_{\text {net }} /$ $C_{\mathrm{i}}$ ) was determined by the relationship between the net assimilation rate and the intercellular $\mathrm{CO}_{2}$ concentration $\left(C_{\mathrm{i}}, \mu \mathrm{mol} \mathrm{CO} \mathrm{Col}_{2}^{-1}\right.$ air $)$.

To ensure that the experimental conditions were consistent, the PPFD was standardized through the use of a light-emitting diode coupled to a photosynthesis chamber, and the light-emitting diode emitted $1500 \mu \mathrm{mol} \mathrm{m}^{-2} \mathrm{~s}^{-1}$, as this is the saturating luminosity, according to a light curve previously performed (Amaro et al., 2014). The reference $\mathrm{CO}_{2}$ concentration that was used during the evaluation was the ambient value, which ranged from 380 to $400 \mu \mathrm{mol} \mathrm{mol}^{-1}$ of air.

\subsection{Biochemical analyses}

The leaf blades were collected and placed in plastic bags, wrapped in aluminum and immediately frozen in liquid nitrogen to stop all metabolic reactions. The leaf blade samples were stored in a $-80{ }^{\circ} \mathrm{C}$ freezer for further analysis.

\subsubsection{Measurement of nitrate reductase activity}

For the determination of the activity of the nitrate reductase enzyme (EC 1.6.6.1), leaf blades ( $1 \mathrm{~g}$ ) were sliced and placed in a dark vial containing $8 \mathrm{~mL}$ of potassium phosphate buffer $(0.1 \mathrm{M}, \mathrm{pH} 7.0)$ and $\mathrm{KNO}_{3}(0.02 \mathrm{M})$. Thereafter, the vials were incubated for one hour at $37{ }^{\circ} \mathrm{C}$ in the absence of light. After this period, $1 \mathrm{~mL}$ of sulfanilamide solution (1\%) and $1 \mathrm{~mL}$ of $\mathrm{N}$-Naphthyl solution (0.02\%) were added and then incubated at $37^{\circ} \mathrm{C}$ in the dark for $5 \mathrm{~min}$. After this period, the nitrate reductase activity was determined spectrophotometrically at $540 \mathrm{~nm}$. A nitrite solution was used to construct the standard curve (Streeter and Bosler, 1972).

\subsubsection{Measurement of antioxidant enzyme activities and lipid peroxidation}

For enzyme extracts, the leaf blades $(300 \mathrm{mg}$ ) were pulverized in liquid nitrogen and homogenized in $4 \mathrm{~mL}$ of pre-cooled potassium phosphate buffer $(0.1 \mathrm{M}, \mathrm{pH} 6.8)$ and $200 \mathrm{mg}$ PVP. The homogenates were centrifuged at $10,000 \times g$ for $10 \mathrm{~min}$ at $4{ }^{\circ} \mathrm{C}$, and the resulting supernatants were used for enzyme assays (Kar and Mishra, 1976). The soluble protein content was determined using casein as a standard (Bradford, 1976). The supernatant from the extraction was used to determine the activities of the enzymes superoxide dismutase (SOD, EC 1.15.1.1), peroxidase (POD, EC 1.11.1.7) and catalase (CAT, EC 1.11.1.6).

The SOD activity was determined by spectrophotometrically 
measuring the photochemical inhibition of nitroblue tetrazolium (NBT) at $560 \mathrm{~nm}$ (Peixoto et al., 1999). One unit of SOD activity (U) was defined as the amount of enzyme required to inhibit the NBT photoreduction by $50 \%$, and the specific activity of the enzyme was expressed as $\mathrm{U} \mathrm{mg}^{-1}$ protein.

POD activity was determined in a spectrophotometer by measuring the formation of purpurogallin at $430 \mathrm{~nm}$ (Teisseire and Guy, 2000), and the activity was expressed in $\mu \mathrm{mol}$ of purpurogallin $\mathrm{min}^{-1} \mathrm{mg}^{-1}$ protein. The activity of CAT was assayed by monitoring $\mathrm{H}_{2} \mathrm{O}_{2}$ consumption at $240 \mathrm{~nm}$ for $80 \mathrm{~s}$ (Peixoto et al., 1999), and the activity was expressed in nmol of $\mathrm{H}_{2} \mathrm{O}_{2}$ consumed $\mathrm{min}^{-1} \mathrm{mg}^{-1}$ protein.

For the lipid peroxidation assay, the leaf blades (200-400 mg) were pulverized in liquid nitrogen and homogenized in $5 \mathrm{~mL}$ of solution containing $0.25 \%$ thiobarbituric acid (TBA) and $10 \%$ trichloroacetic acid (TCA). The extracted solution was incubated in a water bath at $90{ }^{\circ} \mathrm{C}$ for $60 \mathrm{~min}$. After cooling, the solution was centrifuged at 10,000 $\mathrm{xg}$ for $15 \mathrm{~min}$ at room temperature $\left(25^{\circ} \mathrm{C}\right)$. The supernatant collected from each sample was subjected to spectrophotometric absorbance readings at 560 and $600 \mathrm{~nm}$. For the calculations, the molar extinction coefficient of malondialdehyde $\left(155 \mathrm{mmol} \mathrm{L}^{-1} \mathrm{~cm}^{-1}\right.$ ) was used (Rama Devi and Prasad, 1998).

\subsection{Fruit production}

Fruit harvesting was performed daily starting at 31 DAT and ending at 80 DAT. We evaluated the number of fruits $\mathrm{m}^{-2}$, yield $\left(\mathrm{kg} \mathrm{m}^{-2}\right)$ and average weight $\left(\mathrm{g}\right.$ fruit $^{-1}$ ) when they were $20-25 \mathrm{~cm}$ long and $2.0-3.0 \mathrm{~cm}$ in diameter.

\subsection{Statistical analyses}

The statistical package used for the data analysis was SAS 9.2 (SAS Institute Inc., Cary, NC). The Levene test was used to verify the homogeneity of variances of the treatments. The data were examined using analysis of variance (ANOVA). The experimental design was completely randomized in a $2 \times 5$ factorial scheme, with grafted and ungrafted cucumber plants and 5 treatments with fungicides. The means were compared using Tukey test $(P \leq 0.05)$.

\section{Results}

The Levene test showed that the variances were homogeneous among the treatments and grafting for all variables analyzed.

\subsection{Gas exchange}

The significant interaction treatments $\mathrm{x}$ grafting was detected for gas exchanges $(P<0.001)$, except for $\mathrm{g}_{\mathrm{s}}(P>0.05)$. At the beginning of fruit production (35 DAT), grafted plants treated with pyraclostrobin and boscalid alone presented the highest $A_{\text {net }}$ and $A_{\text {net }} / C_{i}$ despite there being no statistically significant differences between their WUE and $g_{s}$ and those of control plants (Table 1). However, at the peak (57 DAT) and final fruit production (73 DAT), there was an increase in the gas exchange rates $\left(A_{\text {net }}, W U E\right.$ and $\left.A_{\text {net }} / C_{i}\right)$ of the control plants. The gas exchange rates of the control plants remained higher than those of the plants treated with the fungicides but did not differ from the plants treated with pyraclostrobin and boscalid alone, whereas they did not decrease in relation to the previous evaluation. Plants treated with azoxystrobin had the lowest rates of gas exchange $\left(A_{\text {net }}\right.$ and $\left.A_{\text {net }} / C_{i}\right)$ throughout the experiment (Table 1).

Ungrafted plants treated with azoxystrobin had the lowest rates of gas exchange $\left(A_{\text {net }}\right.$, WUE and $\left.A_{\text {net }} / C_{i}\right)$ at the beginning of fruit production (35 DAT); however, the gas exchange rates of the plants receiving the other treatments with did not differ from those of the control (Table 1). At the peak of fruit production (57 DAT), all fungicide treatments efficiently increased the gas exchange rates $\left(A_{\text {net }}, W U E\right.$ and
$A_{\text {net }} / C_{i}$ ) of ungrafted plants, and the strobilurin (azoxystrobin and pyraclostrobin) treatments were the most efficient. At the end of fruit production (73 DAT), plants treated with azoxystrobin or the mixture of pyraclostrobin and boscalid maintained higher $A_{\text {net }}$ and $A_{\text {net }} / C_{i}$, but these values did not differ statistically from those of control plants (Table 1).

In general, at 35 DAT, the application of azoxystrobin, boscalid and pyraclostrobin increased the gas exchange of the grafted plants; however, this response was not maintained in the other time points (Table 1).

\subsection{Fungicide effects on nitrate reductase activity}

The significant interaction treatments $\mathrm{x}$ grafting was detected for nitrate reductase activity $(P<0.001)$. At the beginning of fruit production (35 DAT), all fungicides efficiently increased the activity of the nitrate reductase enzyme in the grafted plants in relation to the control (Table 2), and the plants treated with pyraclostrobin, azoxystrobin or boscalid alone presented the highest values. The ungrafted plants treated with pyraclostrobin alone showed the highest activity of the nitrate reductase enzyme. Plants treated with the mixture of pyraclostrobin and boscalid showed the second highest activity of the nitrate reductase enzyme, but this activity did not differ from that in plants treated with azoxystrobin or boscalid alone (Table 2). It was also observed that at 35 DAT, the application of azoxystrobin or boscalid alone increased nitrate reductase activity in the grafted plants relative to that in the ungrafted plants.

At the peak of fruit production (57 DAT), ungrafted plants treated with pyraclostrobin alone continued to show the highest activity of the nitrate reductase enzyme in, but this activity did not differ from that in plants treated with azoxystrobin (Table 2). In the grafted plants, the effects of treatments with fungicides did not differ from those of the control. At the end of the harvest (73 DAT), grafted plants treated with the fungicides showed less activity of the enzyme nitrate reductase. However, ungrafted plants treated with strobilurins (pyraclostrobin alone and azoxystrobin) remained similar to the controls (Table 2).

\subsection{Effects of fungicides on antioxidant enzyme activity and lipid peroxidation}

The significant interaction treatments $\times$ grafting was detected for antioxidant enzyme activity and lipid peroxidation $(P<0.001)$. The ungrafted plants treated with the pyraclostrobin and boscalid mixture showed an increase in the activity of the antioxidative system. The ungrafted plants presented greater SOD and CAT activities and lower lipid peroxidation than the control plants at 35 (Fig. 1) and 73 DAT (Fig. 3), evidencing their role as a protector against stress. In the grafted plants, this mixture of fungicides was also efficient at combating oxidative stress, as treatment with the mixture presented the lowest level of lipid peroxidation at 35 DAT, as well as higher POD activity in relation to the control despite the activity of SOD being lower (Fig. 1).

The ungrafted plants treated with azoxystrobin presented the highest level of lipid peroxidation at 35 DAT, 50\% higher than in the control treatment. The ungrafted plants also showed high SOD activity but low CAT activity, which is inefficient at this stage in the detoxification of hydrogen peroxide, thus failing to combat stress and explaining the higher lipid peroxidation levels (Fig. 1); however, this finding was not replicated for the other enzymatic collections, because the plants treated with this fungicide showed increased SOD activity in relation to the control at 57 (Fig. 2) and 73 DAT (Fig. 3) and increased POD and CAT at 57 DAT (Fig. 2), showing that the plants had recovered from the stress at the previous evaluation. These findings suggest that enzyme activity was still settling at that time, maintaining low lipid peroxidation levels.

In the grafted plants, among all treatments, azoxystrobin treatment resulted in the lowest activity of antioxidant enzymes (SOD, POD and 
Table 1

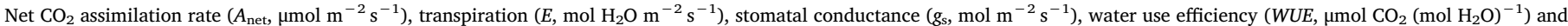
carboxylation efficiency $\left(A_{\text {net }} / C_{\mathrm{i}}\right)$ in ungrafted and grafted Japanese cucumber (C. sativus) leaves sprayed with different fungicides.

\begin{tabular}{|c|c|c|c|c|c|c|c|c|c|c|}
\hline \multicolumn{11}{|l|}{35 DAT } \\
\hline \multirow[t]{2}{*}{ Treatments } & \multicolumn{2}{|l|}{$A_{\text {net }}$} & \multicolumn{2}{|l|}{$E$} & \multicolumn{2}{|l|}{$g_{s}$} & \multicolumn{2}{|l|}{ WUE } & \multicolumn{2}{|l|}{$A_{\text {net }} / C_{\mathrm{i}}$} \\
\hline & Ungrafted & Grafted & Ungrafted & Grafted & Ungrafted & Grafted & Ungrafted & Grafted & Ungrafted & Grafted \\
\hline Control & $22.13 \mathrm{aA}$ & $22.27 \mathrm{bA}$ & $10.80 \mathrm{aA}$ & $9.51 \mathrm{bcA}$ & $0.8047 \mathrm{aA}$ & $0.8584 \mathrm{abA}$ & $2.05 \mathrm{aB}$ & $2.43 \mathrm{abA}$ & $0.0724 \mathrm{aA}$ & $0.0728 \mathrm{bA}$ \\
\hline AZB & $15.62 \mathrm{bB}$ & $18.48 \mathrm{cA}$ & $10.24 \mathrm{aA}$ & $8.80 \mathrm{cB}$ & $0.6866 \mathrm{aA}$ & $0.6415 \mathrm{bA}$ & $1.53 \mathrm{bB}$ & $2.09 \mathrm{bcA}$ & $0.0484 \mathrm{bB}$ & $0.0622 \mathrm{cA}$ \\
\hline BOS & $22.03 \mathrm{aB}$ & $27.50 \mathrm{aA}$ & $10.14 \mathrm{aA}$ & $11.13 \mathrm{abA}$ & $0.8383 \mathrm{aA}$ & $1.1407 \mathrm{aA}$ & $2.17 \mathrm{aB}$ & $2.47 \mathrm{aA}$ & $0.0718 \mathrm{aB}$ & $0.0918 \mathrm{aA}$ \\
\hline PIR & $22.87 \mathrm{aB}$ & $27.17 \mathrm{aA}$ & $10.23 \mathrm{aB}$ & $11.77 \mathrm{aA}$ & $0.7250 \mathrm{aA}$ & $1.0107 \mathrm{abA}$ & $2.26 \mathrm{aA}$ & $2.31 \mathrm{abcA}$ & $0.0781 \mathrm{aB}$ & $0.0910 \mathrm{aA}$ \\
\hline BOS + PIR & $23.33 \mathrm{aA}$ & $21.10 \mathrm{bcB}$ & $10.86 \mathrm{aA}$ & $10.51 \mathrm{abcA}$ & $0.8477 \mathrm{aA}$ & 0.6415 bA & $2.15 \mathrm{aA}$ & $2.03 \mathrm{cA}$ & $0.0775 \mathrm{aA}$ & $0.0714 \mathrm{bcA}$ \\
\hline \multicolumn{11}{|l|}{$\mathrm{F}$ value } \\
\hline Treatments & $37.59 * *$ & & $2.82 *$ & & $3.01 \mathrm{~ns}$ & & $10.80^{* *}$ & & $43.00 * *$ & \\
\hline Grafting & $20.26^{* *}$ & & $0.128 \mathrm{~ns}$ & & $0.754 \mathrm{~ns}$ & & $16.55^{* *}$ & & $27.56^{* *}$ & \\
\hline Treatments x Grafting & $9.008^{* *}$ & & $3.80 *$ & & $2.150 \mathrm{~ns}$ & & $4.52^{* *}$ & & $9.37^{* *}$ & \\
\hline C.V. (\%) & 6.64 & & 9.32 & & 27.62 & & 8.38 & & 6.7 & \\
\hline
\end{tabular}

57 DAT

\begin{tabular}{|c|c|c|c|c|c|c|c|c|c|c|}
\hline \multirow[t]{2}{*}{ Treatments } & \multicolumn{2}{|l|}{$A_{\text {net }}$} & \multicolumn{2}{|l|}{$E$} & \multicolumn{2}{|l|}{$g_{\mathrm{s}}$} & \multicolumn{2}{|l|}{ WUE } & \multicolumn{2}{|l|}{$A_{\text {net }} / C_{\mathrm{i}}$} \\
\hline & Ungrafted & Grafted & Ungrafted & Grafted & Ungrafted & Grafted & Ungrafted & Grafted & Ungrafted & Grafted \\
\hline Control & 23.07 bB & $30.10 \mathrm{aA}$ & $11.00 \mathrm{aA}$ & $10.25 \mathrm{abA}$ & $0.9667 \mathrm{aA}$ & $1.0317 \mathrm{aA}$ & $2.00 \mathrm{bB}$ & $2.94 \mathrm{aA}$ & $0.0780 \mathrm{bB}$ & $0.1095 \mathrm{aA}$ \\
\hline AZB & $28.00 \mathrm{aA}$ & $25.30 \mathrm{bcB}$ & $10.25 \mathrm{aA}$ & $11.03 \mathrm{aA}$ & $1.0900 \mathrm{aA}$ & $0.9390 \mathrm{aA}$ & $2.74 \mathrm{aA}$ & $2.30 \mathrm{bB}$ & $0.0983 \mathrm{aA}$ & $0.0878 \mathrm{bA}$ \\
\hline BOS & $26.42 \mathrm{aA}$ & $27.40 \mathrm{abcA}$ & $10.57 \mathrm{aA}$ & $9.54 \mathrm{bB}$ & $1.0892 \mathrm{aA}$ & $0.8870 \mathrm{aA}$ & $2.51 \mathrm{abB}$ & $2.88 \mathrm{aA}$ & $0.0906 \mathrm{abA}$ & $0.0998 \mathrm{abA}$ \\
\hline PIR & $26.97 \mathrm{aA}$ & $27.80 \mathrm{abA}$ & $10.52 \mathrm{aA}$ & $10.30 \mathrm{abA}$ & $0.9192 \mathrm{aA}$ & $1.126 \mathrm{aA}$ & $2.57 \mathrm{aA}$ & $2.73 \mathrm{abA}$ & $0.0974 \mathrm{aA}$ & $0.0971 \mathrm{abA}$ \\
\hline BOS + PIR & $27.15 \mathrm{aA}$ & $24.40 \mathrm{cB}$ & $10.04 \mathrm{aA}$ & $10.43 \mathrm{abA}$ & $1.1310 \mathrm{aA}$ & $0.7757 \mathrm{aB}$ & $2.71 \mathrm{aA}$ & $2.35 \mathrm{bB}$ & $0.0951 \mathrm{aA}$ & $0.0870 \mathrm{bA}$ \\
\hline \multicolumn{11}{|l|}{$\mathrm{F}$ value } \\
\hline Treatments & $1.24 \mathrm{~ns}$ & & $1.32 \mathrm{~ns}$ & & $0.13 \mathrm{~ns}$ & & $1.21 \mathrm{~ns}$ & & $0.76 \mathrm{~ns}$ & \\
\hline Grafting & $2.05 \mathrm{~ns}$ & & $0.72 \mathrm{~ns}$ & & $1.63 \mathrm{~ns}$ & & $2.94 \mathrm{~ns}$ & & $3.39 \mathrm{~ns}$ & \\
\hline Treatments x Grafting & $14.23^{* *}$ & & $3.00 *$ & & $2.13 \mathrm{~ns}$ & & $12.18^{* *}$ & & $10.18^{* *}$ & \\
\hline C.V. (\%) & 5.61 & & 5.96 & & 21.72 & & 8.36 & & 8 & \\
\hline
\end{tabular}

73 DAT

\begin{tabular}{|c|c|c|c|c|c|c|c|c|c|c|}
\hline \multirow[t]{2}{*}{ Treatments } & \multicolumn{2}{|l|}{$A_{\text {net }}$} & \multicolumn{2}{|l|}{$E$} & \multicolumn{2}{|l|}{$g_{s}$} & \multicolumn{2}{|l|}{ WUE } & \multicolumn{2}{|l|}{$A_{\text {net }} / C_{\mathrm{i}}$} \\
\hline & Ungrafted & Grafted & Ungrafted & Grafted & Ungrafted & Grafted & Ungrafted & Grafted & Ungrafted & Grafted \\
\hline Control & $22.34 \mathrm{abA}$ & $24.07 \mathrm{aA}$ & 10.98 bA & $11.20 \mathrm{aA}$ & $0.6304 \mathrm{aA}$ & $0.7493 \mathrm{aA}$ & $2.03 \mathrm{aA}$ & $1.16 \mathrm{aA}$ & $0.0818 \mathrm{abA}$ & $0.0886 \mathrm{aA}$ \\
\hline AZB & $25.32 \mathrm{aA}$ & $17.80 \mathrm{bB}$ & $11.46 \mathrm{abA}$ & $9.58 \mathrm{bB}$ & 0.8449 aA & $0.7503 \mathrm{aA}$ & $2.21 \mathrm{aA}$ & $2.10 \mathrm{aB}$ & $0.0927 \mathrm{aA}$ & $0.0638 \mathrm{bB}$ \\
\hline BOS & $23.13 \mathrm{abA}$ & $23.37 \mathrm{aA}$ & $12.07 \mathrm{aA}$ & $11.05 \mathrm{aB}$ & $1.0938 \mathrm{aA}$ & $0.6725 \mathrm{aB}$ & $1.92 \mathrm{aA}$ & $2.11 \mathrm{aA}$ & 0.0789 abA & $0.0864 \mathrm{aA}$ \\
\hline PIR & 20.13 bA & $23.67 \mathrm{aB}$ & $10.61 \mathrm{bA}$ & $11.00 \mathrm{aA}$ & $0.9120 \mathrm{aA}$ & $0.6673 \mathrm{aA}$ & $1.89 \mathrm{aB}$ & $2.15 \mathrm{aA}$ & $0.0719 \mathrm{bB}$ & $0.0870 \mathrm{aA}$ \\
\hline BOS + PIR & $24.50 \mathrm{aA}$ & 24.77 aA & $11.37 \mathrm{abA}$ & $11.82 \mathrm{aA}$ & $0.6897 \mathrm{aA}$ & $0.7930 \mathrm{aA}$ & $2.16 \mathrm{aA}$ & $1.86 \mathrm{aA}$ & $0.0914 \mathrm{aA}$ & $0.0899 \mathrm{aA}$ \\
\hline \multicolumn{11}{|l|}{$\mathrm{F}$ value } \\
\hline Treatments & $2.87^{*}$ & & $8.36^{* *}$ & & $0.80 \mathrm{~ns}$ & & $0.71 \mathrm{~ns}$ & & $2.27 \mathrm{~ns}$ & \\
\hline Grafting & $0.29 \mathrm{~ns}$ & & $6.35^{*}$ & & $2.24 \mathrm{~ns}$ & & $0.39 \mathrm{~ns}$ & & $0.01 \mathrm{~ns}$ & \\
\hline Treatments x Grafting & $8.52^{* *}$ & & $10.22^{* *}$ & & $2.06 \mathrm{~ns}$ & & $4.40^{* *}$ & & $6.75^{* *}$ & \\
\hline C.V. (\%) & 8.95 & & 4.13 & & 29.15 & & 8.11 & & 11.17 & \\
\hline
\end{tabular}

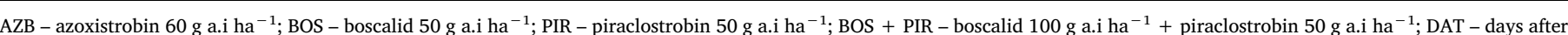

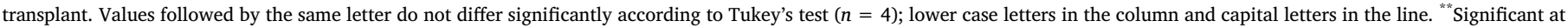
$1 \%$ probability $(P \leq 0.01)$; "significant at $5 \%$ probability $(P \leq 0.05)$; and ns denotes not significant $(P>0.05)$.

CAT) at the beginning and at the end of fruit production (35 and 73 DAT). However, the level of lipid peroxidation remained low, suggesting that enzyme activity had been higher at some earlier time, combating ROS and resulting in a low level of oxidative stress, but at the time of collection, the enzyme activities had already decreased (Figs. 2 and 3). At the peak of production (57 DAT), the activity of SOD, POD and CAT was among the highest (Fig. 2), and as the levels of lipoperoxides were relatively low, we can conclude that oxidative stress had been controlled.

At the end of production (73 DAT), the application of fungicides in the grafted plants decreased the lipid peroxidation levels in relation to those in the control plants. for the exception was the plants treated with pyraclostrobin, which showed lower activities of the antioxidant enzymes SOD, POD and CAT and led to one of the highest lipid peroxidation rates, which was similar to that of the control (Fig. 3).

\subsection{Effects of fungicide on fruit production}

The significant interaction treatments $\mathrm{x}$ grafting was detected for fruit production $(P<0.001)$, except for average weight $(P>0.05)$. In relation to the measures of production, the number of fruits $\mathrm{m}^{-2}$ and productivity $\left(\mathrm{kg} \mathrm{m}^{-2}\right)$, in the ungrafted plants, the application of the mixture of pyraclostrobin with boscalid was the only treatment that increased fruit production (Table 3), resulting in $17 \%$ more fruit and $14 \%$ more productivity; however, the results were not significantly different from those of the control plants. In addition, ungrafted plants did not present significant differences in average fruit mass.

In the grafted plants, all treatments with fungicides increased the number of fruits and the productivity $\left(\mathrm{kg} \mathrm{m}^{-2}\right)$ (Table 3$)$. The plants treated with pyraclostrobin alone produced $64 \%$ more fruits than the control and were $60 \%$ more productive; however, the results were not 
Table 2

Nitrate reductase activity (NR) in ungrafted and grafted Japanese cucumber (C. sativus) leaves sprayed with different fungicides.

\begin{tabular}{|c|c|c|c|c|c|c|}
\hline \multicolumn{7}{|c|}{$\mathrm{NR}, \mu \mathrm{g}$ nitrite $\min ^{-1} \mathrm{~g}^{-1}$} \\
\hline \multirow[t]{2}{*}{ Treatments } & \multicolumn{2}{|l|}{35 DAT } & \multicolumn{2}{|l|}{56 DAT } & \multicolumn{2}{|l|}{73 DAT } \\
\hline & Ungrafted & Grafted & Ungrafted & Grafted & Ungrafted & Grafted \\
\hline Control & $55.95 \mathrm{cA}$ & $61.20 \mathrm{cA}$ & $51.40 \mathrm{bcA}$ & $50.00 \mathrm{aA}$ & $118.39 \mathrm{aB}$ & $164.50 \mathrm{aA}$ \\
\hline AZB & $62.68 \mathrm{bcB}$ & $115.59 \mathrm{aA}$ & $58.64 \mathrm{abA}$ & $49.91 \mathrm{aB}$ & $95.40 \mathrm{abB}$ & $154.92 \mathrm{abA}$ \\
\hline BOS & $70.59 \mathrm{bcB}$ & $107.46 \mathrm{aA}$ & $42.53 \mathrm{cA}$ & 48.25 abA & 64.82 bA & $63.42 \mathrm{cA}$ \\
\hline PIR & $109.87 \mathrm{aA}$ & $111.12 \mathrm{aA}$ & $67.51 \mathrm{aA}$ & $44.40 \mathrm{abB}$ & $123.41 \mathrm{aA}$ & $122.83 \mathrm{bA}$ \\
\hline BOS + PIR & 74.43 bA & 78.94 bA & $54.32 \mathrm{bA}$ & $38.62 \mathrm{cB}$ & 68.91 bA & $68.38 \mathrm{cA}$ \\
\hline \multicolumn{7}{|l|}{ F value } \\
\hline Treatments & $48.83^{* *}$ & & $7.14^{* *}$ & & $32.38^{* *}$ & \\
\hline Grafting & $68.42^{* *}$ & & $30.90^{* *}$ & & $13.62^{* *}$ & \\
\hline Treatments x Grafting & $18.32^{* *}$ & & $10.71^{* *}$ & & $5.68^{* *}$ & \\
\hline C.V. (\%) & 9.09 & & 9.73 & & 16.91 & \\
\hline
\end{tabular}

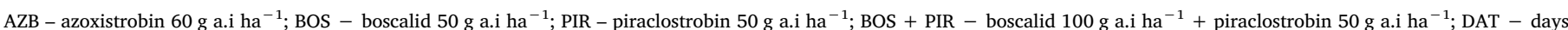

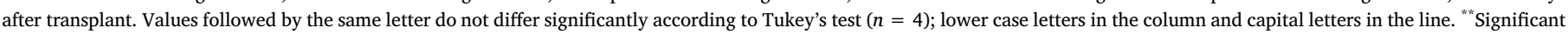
at $1 \%$ probability $(P \leq 0.01)$; "significant at $5 \%$ probability $(P \leq 0.05)$; and ns denotes not significant $(P>0.05)$.

significantly different from those of the plants treated with boscalid alone. Plants treated with boscalid had $40 \%$ more fruits and we $34 \%$ more productive.

The mixture of pyraclostrobin and boscalid in the grafted plants resulted in $17 \%$ more fruits and $11 \%$ greater productivity than in the control plants, but there were no significant differences; the increases were similar to those in ungrafted plants. This result indicates that the efficiency had not diminished; rather, the efficiency of the other

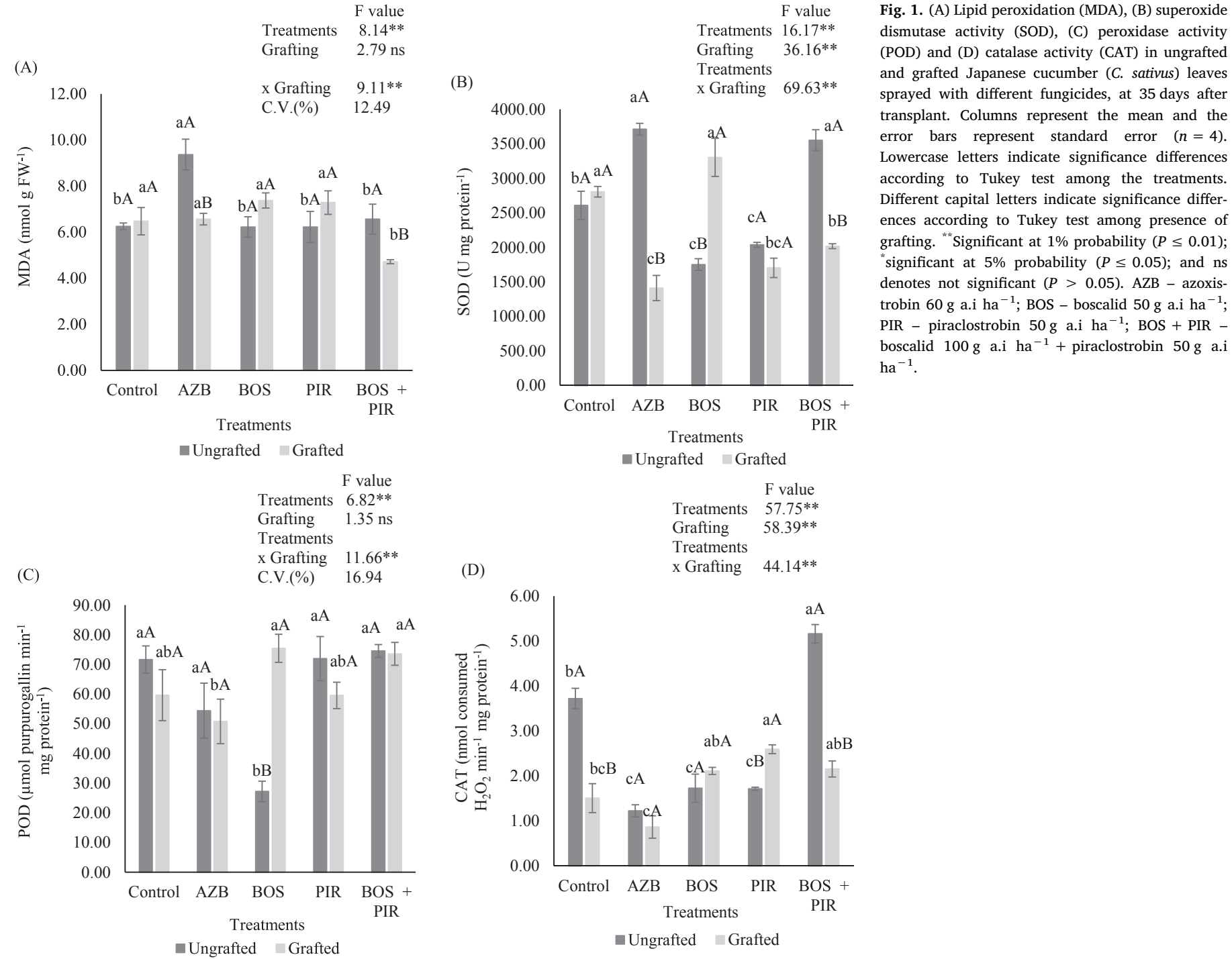



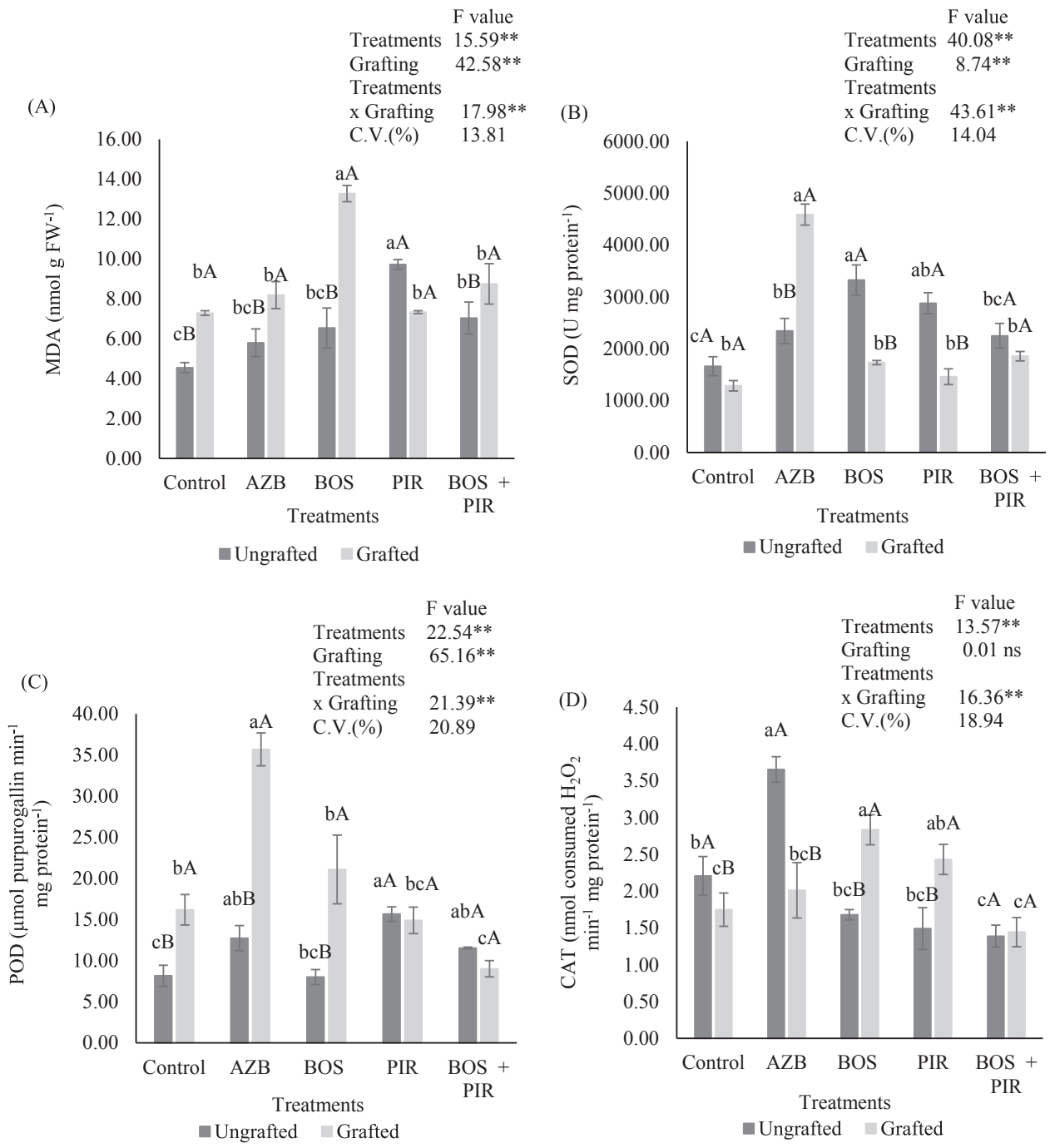

Fig. 2. (A) Lipid peroxidation (MDA), (B) superoxide dismutase activity (SOD), (C) peroxidase activity (POD) and (D) catalase activity (CAT) in ungrafted and grafted Japanese cucumber (C. sativus) leaves sprayed with different fungicides, at 57 days after transplant. Columns represent the mean and the error bars represent standard error $(n=4)$. Lowercase letters indicate significance differences according to Tukey test among the treatments. Different capital letters indicate significance differences according to Tukey test among presence of grafting. "** Significant at $1 \%$ probability $(P \leq 0.01)$; "significant at $5 \%$ probability $(P \leq 0.05)$; and ns denotes not significant $(P>0.05)$. AZB - azoxistrobin $60 \mathrm{~g}$ a.i ha ${ }^{-1}$; BOS boscalid $50 \mathrm{~g}$ a.i ha ${ }^{-1}$; PIR - piraclostrobin $50 \mathrm{~g}$ a.i $\mathrm{ha}^{-1} ; \quad$ BOS + PIR - boscalid $100 \mathrm{~g}$ a.i $\mathrm{ha}^{-1}+$ piraclostrobin $50 \mathrm{~g}$ a.i ha ${ }^{-1}$. fungicides had increased. However, the plants treated with azoxystrobin presented heavier fruits although they did not differ from those of the control plants (Table 3).

Regarding the absence or presence of grafting, some differences were also found. The ungrafted plants controlled and treated with the mixture of pyraclostrobin and boscalid showed higher productivity and a greater number of fruits than the grafted plants (Table 3). However, when the grafted plants were treated with pyraclostrobin alone, this result was opposite, with the grafted plants showing greater fruit number and productivity.

\section{Discussion}

In the present study, it was verified that the different strobilurins tested exert different physiological effects on the plants to which they are applied, possibly due to their different formulations. While the application of pyraclostrobin resulted in an improvement in the physiological performance of grafted cucumber plants, treatment with azoxystrobin had no such effect. Similar results were found in the literature, where it was reported that the application of azoxystrobin also decreased the rate of net $\mathrm{CO}_{2}$ assimilation, transpiration rate, stomatal conductance and internal carbon concentration in the substomatal chamber in wheat (Nason et al., 2007), barley (Nason et al., 2007), soybean (Nason et al., 2007) and rice (Debona et al., 2016). One possible explanation for these results is that the reduction of ATP production caused by the blockade of electron transport in the cytochrome $\mathrm{bc}_{1}$ complex may, instead of increasing the rate of $\mathrm{CO}_{2}$ assimilation by temporarily reducing respiration, cause the normal functioning of metabolism in guard cells, reducing turgor and consequently stomatal opening, as the osmotic potential of guard cells is limited by the production of ATP (Nason et al., 2007). The same authors verified that the ratio of $\mathrm{Fv} / \mathrm{Fm}$ is also decreased in soybean plants, which indicates that photosynthesis is directly inhibited, perhaps independently of what might have occurred in the stomata. One possible explanation is that these strobilurins block the transport of electrons between photosystem II I and photosystem I (PSI) by binding to the Qi site of the chloroplast bf cytochrome complex (Nason et al., 2007).

In this experiment, the application of fungicides to the ungrafted plants did not generally influence the levels of lipid peroxidation; they remained similar to those of the control plants, evidencing the absence of stress. The few positive physiological effects found in ungrafted plants were not sufficient to result in higher productivity.

The present study showed that fungicide treatments presented different responses between grafted and ungrafted plants. In the present work, the physiological benefits of the fungicides were more noticeable in the grafted plants, and the fungicides tested showed benefits in the production of fruits, to a greater or lesser extent, in this type of plant.

The physiology of grafted plants tends to be different from that of ungrafted plants due to graft and rootstock ratios. It is worth remembering that unlike plants that are not grafted, grafted plants undergo initial stress in the post-grafting restablishment, since they have to adapt to the union between graft and rootstock to complete the 


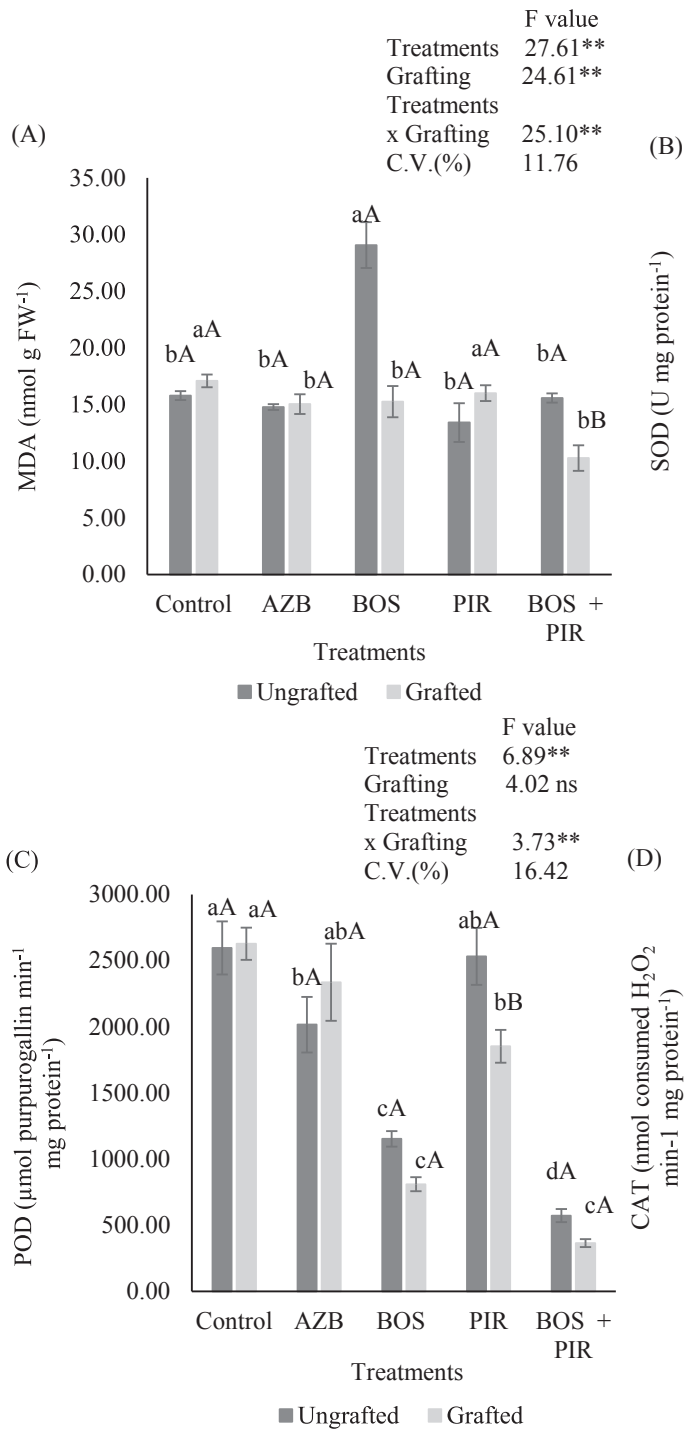

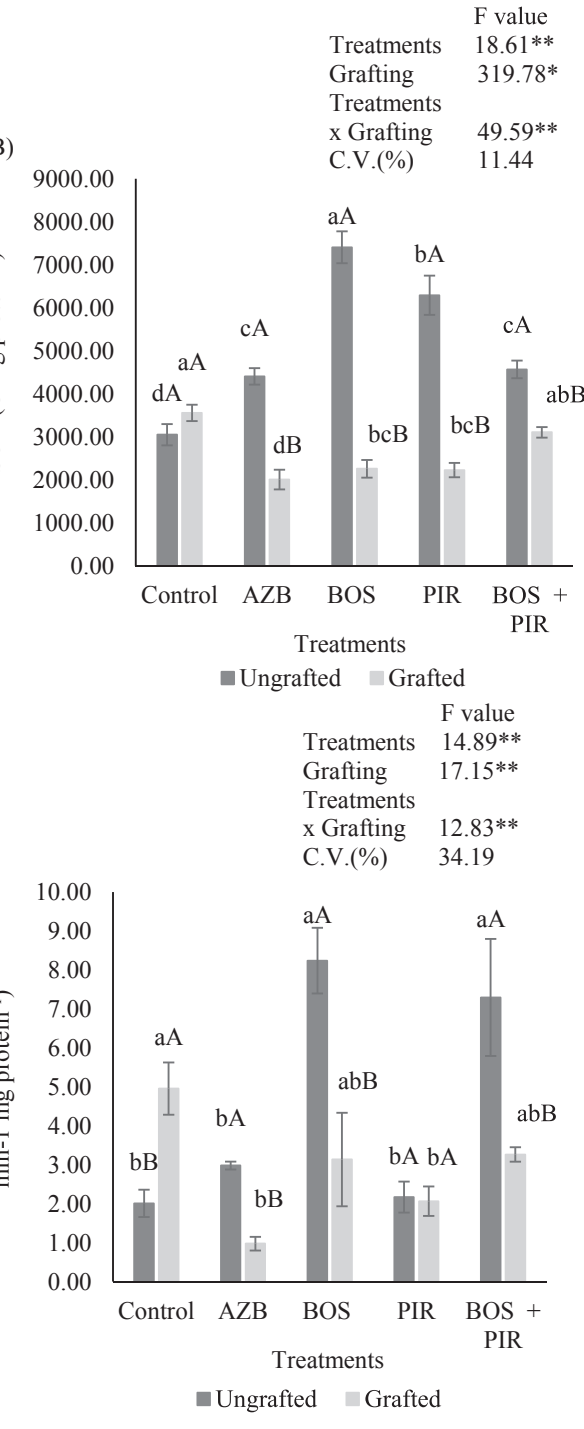

Fig. 3. (A) Lipid peroxidation (MDA), (B) superoxide dismutase activity (SOD), (C) peroxidase activity (POD) and (D) catalase activity (CAT) in ungrafted and grafted Japanese cucumber (C. sativus) leaves sprayed with different fungicides, at 73 days after transplant. Columns represent the mean and the error bars represent standard error $(n=4)$. Lowercase letters indicate significance differences according to Tukey test among the treatments. Different capital letters indicate significance differences according to Tukey test among presence of grafting. "*significant at $1 \%$ probability $(P \leq 0.01)$; "significant at $5 \%$ probability $(P \leq 0.05)$; and ns denotes not significant $(P>0.05)$. AZB - azoxistrobin $60 \mathrm{~g}$ a.i ha ${ }^{-1}$; BOS boscalid $50 \mathrm{~g}$ a.i ha ${ }^{-1}$; PIR - piraclostrobin $50 \mathrm{~g}$ a.i $\mathrm{ha}^{-1}$; $\quad$ BOS + PIR $\quad-$ boscalid $100 \mathrm{~g}$ a.i $\mathrm{ha}^{-1}+$ piraclostrobin $50 \mathrm{~g}$ a.i ha ${ }^{-1}$. vascular connection (Irisarri et al., 2015; Liu et al., 2014). However, over time, the grafted plants will have more advantages than the ungrafted plants because of the vigor of the rootstock, as observed in this experiment.

Most studies of grafting suggest that changes in the scion are controlled by the rootstock through controlled uptake, synthesis, and translocation of water, minerals, and plant hormones (MartínezBallesta et al., 2010). Moreover, a rootstock can improve tolerance to heavy metals and organic pollutants (Savvas et al., 2010), increases plant strength and increases resistance to abiotic stress, such as low temperatures (Ahn et al., 1999; Schwarz et al., 2010; Venema et al., 2008), drought (Rouphael et al., 2010; Schwarz et al., 2010) and

Table 3

Number of fruits $\mathrm{m}^{-2}$, yield and average weight in ungrafted and grafted Japanese cucumber (C. sativus) leaves sprayed with different fungicides.

\begin{tabular}{|c|c|c|c|c|c|c|}
\hline \multirow[t]{2}{*}{ Treatments } & \multicolumn{2}{|c|}{ Number of fruits $\mathrm{m}^{-2}$} & \multicolumn{2}{|c|}{ Yield $\left(\mathrm{kg} \mathrm{m}^{-2}\right)$} & \multicolumn{2}{|c|}{ Average weight ( $\mathrm{g}$ fruit $^{-1}$ ) } \\
\hline & Ungrafted & Grafted & Ungrafted & Grafted & Ungrafted & Grafted \\
\hline Control & 30.76 abA & $22.17 \mathrm{cB}$ & 3.85 abA & $2,82 \mathrm{cB}$ & $125,27 \mathrm{aA}$ & $129,64 \mathrm{abA}$ \\
\hline AZB & $24.30 \mathrm{bA}$ & $25.33 \mathrm{bcA}$ & $3.08 \mathrm{bB}$ & 3,77 abcA & $127,03 \mathrm{aB}$ & $147,17 \mathrm{aA}$ \\
\hline BOS & $26.10 \mathrm{bA}$ & $31.08 \mathrm{abA}$ & $3.23 \mathrm{bA}$ & 3,79 abA & $123,92 \mathrm{aA}$ & $122,35 \mathrm{bA}$ \\
\hline PIR & $27.56 \mathrm{bB}$ & $36.37 \mathrm{aA}$ & $3.19 \mathrm{bB}$ & $4,51 \mathrm{aA}$ & 116,17 aA & $123,82 \mathrm{bA}$ \\
\hline BOS + PIR & $36.13 \mathrm{aA}$ & $25.96 \mathrm{bcB}$ & $4.39 \mathrm{aA}$ & $3,13 \mathrm{bcB}$ & $122,03 \mathrm{aA}$ & $120,62 \mathrm{bA}$ \\
\hline \multicolumn{7}{|l|}{$\mathrm{F}$ value } \\
\hline Treatments & $5.73^{* *}$ & & $1.80 \mathrm{~ns}$ & & $5.21 * *$ & \\
\hline Grafting & $0.49 \mathrm{~ns}$ & & $0.12 \mathrm{~ns}$ & & $4.65^{*}$ & \\
\hline Treatments x Grafting & $11.00 * *$ & & $11.88^{* *}$ & & $2.16 \mathrm{~ns}$ & \\
\hline C.V. (\%) & 12.44 & & 13.01 & & 6.81 & \\
\hline
\end{tabular}

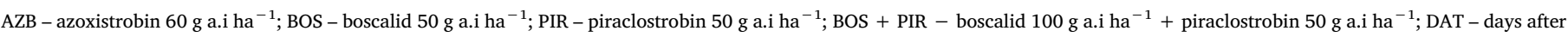

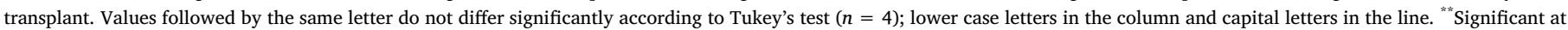
$1 \%$ probability $(P \leq 0.01)$; "significant at $5 \%$ probability $(P \leq 0.05)$; and ns denotes not significant $(P>0.05)$. 
salinity (Albacete et al., 2009; Colla et al., 2012), modifies genes expression levels (Baron et al., 2016) as well as controlling physiological disorders (Martínez-Ballesta et al., 2010) and improving fruit quality (Davis et al., 2008; Flores et al., 2010; Rouphael et al., 2010), thus all these factors result in higher production and increase the harvest period. As a result of this metabolic change, grafting affects photosynthetic metabolism by means of net $\mathrm{CO}_{2}$ assimilation rate improvement and decrease of the maximum quantum yield of photosynthesis (Amaro et al., 2014).

The higher productivity of grafted plants treated with fungicides may have occurred due to the better physiological performance of these plants, especially at the beginning of fruit production. Similar results were observed in soybean (Soares et al., 2011) and corn (Barbosa et al., 2011), where a marked increase of nitrate reductase enzyme activity occurred at the beginning of plant development. The nitrate reductase activity changes according to the plant's life stage; thus, it has its greatest activity in growth organs when they are young since these organs require large amounts of nitrate (Larcher, 2006). In grapes (Berkelmann-Loehnertz et al., 2001), corn (Blandino et al., 2012), soybeans (Fagan et al., 2010) and beans (Jadoski et al., 2015), the application of different strobilurins also increased $\mathrm{CO}_{2}$ assimilation rates.

The plants grafted and treated with pyraclostrobin or boscalid alone were those that produced the most fruits and presented higher productivity. Increases in productivity after the application of strobilurins have also been reported in tomatoes (Cantore et al., 2016), grapes (Berkelmann-Loehnertz et al., 2001; Diaz-Espejo et al., 2012), wheat (Ishikawa et al., 2012; Jørgensen and Olesen, 2002; Kildea et al., 2010; Ruske et al., 2003), corn (Barbosa et al., 2011; Blandino et al., 2012), beans (Jadoski et al., 2015; Kozlowski et al., 2009), soybeans (Fagan et al., 2010; Soares et al., 2011) and Butterhead lettuce (Bonasia et al., 2013). The higher production of fruits of these plants was possibly due to the greater assimilation of $\mathrm{CO}_{2}$ and the better use of nitrogen.

Pyraclostrobin is member of the $\mathrm{Q}_{\mathrm{o}} \mathrm{I}_{\mathrm{s}}$, or inhibitors of the $\mathrm{bc}_{1}$ complex, which inhibit the transfer of electrons in complex III of the respiratory chain, also known as the $\mathrm{bc}_{1}$ cytochrome complex (Balba, 2007; Bartlett et al., 2002; Sauter et al., 1999). Thus, pyraclostrobin alters the $\mathrm{CO}_{2}$ compensation point, temporarily decreasing plant respiration, which increases the rate of net $\mathrm{CO}_{2}$ assimilation; it is worth noting that the bc1 complex is present in all eukaryotic organisms (Grossmann and Retzlaff, 1997). This partial inhibition of the electron transport chain by strobilurins causes a decrease in cellular levels of ATP and, consequently, an increase in the concentration of protons $\left(\mathrm{H}^{+}\right)$in the cytosol, momentarily decreasing the $\mathrm{pH}$ (acidification). This result is due to the decrease in ATPase activity, delaying the pumping of protons from the cytosol $\left(\mathrm{H}^{+}\right)$to the apoplast and leading to increased nitrate reductase activity, as the activity of this enzyme this is regulated by the $\mathrm{pH}$ of the cytosol (Glaab and Kaiser, 1999).

Nitrate reductase catalyzes the first nitrate uptake step from the soil and is considered key to the increase in the biomass of the plants treated with strobilurin, since this increase requires assimilation of large amounts of nitrogen, which is incorporated into organic molecules, such as amino acids and nucleotides, that are essential for plant growth (Koehle et al., 2002).

Boscalid is a succinate dehydrogenase inhibitor (SDHI) and inhibits the transport of electrons in mitochondria, but in an earlier complex, complex II (Avenot and Michailides, 2010; Semar et al., 2011; Stammler et al., 2007; Stammler et al., 2008; Stammler and Speakman, 2006). As with strobilurin, it was observed that boscalid also temporarily decreases plant respiration, which results in an increase in the net assimilation rate of $\mathrm{CO}_{2}$ and an increase in the activity of the nitrate reductase enzyme, probably due to the acidification of the cytosol caused by the increase in the concentration of protons $\left(\mathrm{H}^{+}\right)$.

In addition to the improvement of nitrogen metabolism, strobilurins also act on the hormonal balance of plants, as they reduce the synthesis of ethylene and increase the synthesis and decrease the degradation of cytokinins. As a result, these plants present a reduction of chlorophyll degradation, causing what is called a "green effect", delaying the yellowing of the leaves caused by the degradation of chlorophyll (Grossmann et al., 1999; Grossmann and Retzlaff, 1997; Ruske et al., 2003; Sarwat et al., 2013; Ypema and Gold, 1999). The reduction of chlorophyll degradation, combined with better nitrogen utilization, slows plant senescence and contributes to the increase in the net assimilation rate of $\mathrm{CO}_{2}$, since chlorophyll is an essential component for photosynthesis, and it absorbs energy and directs it to the photosystems (Hörtensteiner and Kräutler, 2011). Increased photosynthetic activity in the leaves has been noted as the main factor for the increase of the productivity of the plants treated with strobilurins, since the delay of the senescence, even for a few days, tends to increase production (Bertelsen et al., 2001). The delay in senescence can be observed due to lower lipid peroxidation in relation to the control plants found at the end of the evaluations, indicating lower oxidative stress.

\section{Conclusion}

Based on the results obtained, it was concluded that the fungicide treatments presented different responses between grafted and ungrafted plants. The physiological benefits were more evident in the grafted plants treated with pyraclostrobin or boscalid alone, and these benefits manifested in terms of fruit production and increased the activity of the antioxidative system, thereby reducing stress. The higher productivity probably occurred due to the better physiological performance of these plants, mainly at the beginning of development, presenting greater activity of the enzyme nitrate reductase, in addition to the higher $A_{\text {net }}$ and $A_{\text {net }} / C_{\mathrm{i}}$.

\section{Acknowledgments}

The authors thank the Fundação de Amparo à Pesquisa do Estado de São Paulo (FAPESP) (grant number 2008/56632-7) for its financial support of this study and to Prof.a Dr.a Martha Maria Mischan (Universidade Estadual Paulista, Instituto de Biociências, Departamento de Bioestatística) for the substantial help with the statistics and to Prof.a Dr.a Rumy Goto (Universidade Estadual Paulista, Faculdade de Ciências Agronômicas, Departamento de Horticultura) for the substantial help with the conduction of this experiment.

\section{References}

Ahn, S.J., Im, Y.J., Chung, G.C., Cho, B.H., Suh, S.R., 1999. Physiological responses of grafted-cucumber leaves and rootstock roots affected by low root temperature. Sci. Hortic. 81, 397-408. http://dx.doi.org/10.1016/S0304-4238(99)00042-4.

Albacete, A., MartíNez-AndÚJar, C., Ghanem, M.E., Acosta, M., SÁNchez-Bravo, J., Asins, M.J., Cuartero, J., Lutts, S., Dodd, I.C., PÉRez-Alfocea, F., 2009. Rootstock-mediated changes in xylem ionic and hormonal status are correlated with delayed leaf senescence, and increased leaf area and crop productivity in salinized tomato. Plant Cell Environ. 32 (7), 928-938. http://dx.doi.org/10.1111/j.1365-3040.2009.01973.x.

Amaro, A.C.E., Macedo, A.C., Ramos, A.R.P., Goto, R., Ono, E.O., Rodrigues, J.D., 2014. The use of grafting to improve the net photosynthesis of cucumber. Theor. Exp. Plant Physiol. 26, 241-249. http://dx.doi.org/10.1007/s40626-014-0023-1.

Avenot, H.F., Michailides, T.J., 2010. Progress in understanding molecular mechanisms and evolution of resistance to succinate dehydrogenase inhibiting (SDHI) fungicides in phytopathogenic fungi. Crop Prot. 29, 643-651. http://dx.doi.org/10.1016/j. cropro.2010.02.019.

Balba, H., 2007. Review of strobilurin fungicide chemicals. J. Environ. Sci. Health Part B 42, 441-451. http://dx.doi.org/10.1080/03601230701316465.

Barbosa, K.A., Fagan, E.B., Casaroli, D., de Carvalho Canedo, S., Teixeira, W.F., 2011. Aplicação de estrobilurina na cultura do milho: alterações fisiológicas e bromatológicas. Rev. Centro Univ. Patos de Minas 2, 20-29.

Baron, D., Bravo, J.P., Maia, I.G., Pina, A., Ferreira, G., 2016. UGP gene expression and UDP-glucose pyrophosphorylase enzymatic activity in grafting annonaceous plants. Acta Physiol. Plant. 38, 79-86. http://dx.doi.org/10.1007/s11738-016-2097-7.

Bartlett, D.W., Clough, J.M., Godwin, J.R., Hall, A.A., Hamer, M., Parr-Dobrzanski, B., 2002. The strobilurin fungicides. Pest Manag. Sci. 58, 649-662. http://dx.doi.org/10. 1002/ps.520.

Berkelmann-Loehnertz, B., Dorn, C., Baus-Reichel, O., Griebel, T., 2001. Impact of strobilurins on grapevine physiology under greenhouse conditions. IOBC WPRS Bull. 24, 303-307. 
Bertelsen, J.R., De Neergaard, E., Smedegaard-Petersen, V., 2001. Fungicidal effects of azoxystrobin and epoxiconazole on phyllosphere fungi, senescence and yield of winter wheat. Plant Pathol. 50, 190-205. http://dx.doi.org/10.1046/j.1365-3059. 2001.00545.x.

Blandino, M., Galeazzi, M., Savoia, W., Reyneri, A., 2012. Timing of azoxystrobin + propiconazole application on maize to control northern corn leaf blight and maximize grain yield. Field Crops Res. 139, 20-29. http://dx.doi.org/10.1016/j.fcr.2012.09. 014.

Bonasia, A., Conversa, G., Lazzizera, C., Elia, A., 2013. Pre-harvest nitrogen and Azoxystrobin application enhances postharvest shelf-life in Butterhead lettuce. Postharvest Biol. Technol. 85, 67-76. http://dx.doi.org/10.1016/j.postharvbio.2013. 04.012 .

Bradford, M.M., 1976. A rapid and sensitive method for the quantitation of microgram quantities of protein utilizing the principle of protein-dye binding. Anal. Biochem. 72, 248-254. http://dx.doi.org/10.1016/0003-2697(76)90527-3.

Cantore, V., Lechkar, O., Karabulut, E., Sellami, M.H., Albrizio, R., Boari, F., Stellacci, A.M., Todorovic, M., 2016. Combined effect of deficit irrigation and strobilurin application on yield, fruit quality and water use efficiency of cherry tomato (Solanum lycopersicum L.). Agric. Water Manage. 167, 53-61. http://dx.doi.org/10.1016/j. agwat.2015.12.024.

Colla, G., Rouphael, Y., Rea, E., Cardarelli, M., 2012. Grafting cucumber plants enhance tolerance to sodium chloride and sulfate salinization. Sci. Hortic. 135, 177-185. http://dx.doi.org/10.1016/j.scienta.2011.11.023.

Davis, A.R., Perkins-Veazie, P., Hassell, R., Levi, A., King, S.R., Zhang, X., 2008. Grafting effects on vegetable quality. HortScience 43, 1670-1672.

Debona, D., Nascimento, K.J.T., Gomes, J.G.O., Aucique-Perez, C.E., Rodrigues, F.A., 2016. Physiological changes promoted by a strobilurin fungicide in the rice-bipolaris oryzae interaction. Pestic. Biochem. Physiol. 130, 8-16. http://dx.doi.org/10.1016/j. pestbp.2015.12.006

Diaz-Espejo, A., Cuevas, M.V., Ribas-Carbo, M., Flexas, J., Martorell, S., Fernández, J.E., 2012. The effect of strobilurins on leaf gas exchange, water use efficiency and ABA content in grapevine under field conditions. J. Plant Physiol. 169, 379-386. http:// dx.doi.org/10.1016/j.jplph.2011.11.014.

Fagan, E.B., Dourado Neto, D., Vivian, R., Franco, R.B., Yeda, M.P., Massignam, L.F., Oliveira, R.F.d, Martins, K.V., 2010. Efeito da aplicação de piraclostrobina na taxa fotossintética, respiração, atividade da enzima nitrato redutase e produtividade de grãos de soja. Bragantia 69, 771-777. http://dx.doi.org/10.1590/S0006 87052010000400001

Flores, F.B., Sanchez-Bel, P., Estañ, M.T., Martinez-Rodriguez, M.M., Moyano, E., Morales, B., Campos, J.F., Garcia-Abellán, J.O., Egea, M.I., Fernández-Garcia, N., Romojaro, F., Bolarín, M.C., 2010. The effectiveness of grafting to improve tomato fruit quality. Sci. Hortic. 125, 211-217. http://dx.doi.org/10.1016/j.scienta.2010.03.026.

Glaab, J., Kaiser, W.M., 1999. Increased nitrate reductase activity in leaf tissue after application of the fungicide Kresoxim-methyl. Planta 207, 442-448. http://dx.doi. org/10.1007/s004250050503.

Grossmann, K., Retzlaff, G., 1997. Bioregulatory effects of the fungicidal strobilurin kresoxim-methyl in wheat (Triticum aestivum). Pestic. Sci. 2-8. http://doi.org/10. 1002/(SICI)1096-9063(199705)50:1 < 11::AID-PS556 > 3.0.CO;2-8.

Grossmann, K., Kwiatkowski, J., Caspar, G., 1999. Regulation of phytohormone levels, leaf senescence and transpiration by the strobilurin kresoxim-methyl in wheat (Triticum aestivum). J. Plant Physiol. 154, 805-808. http://dx.doi.org/10.1016, S0176-1617(99)80262-4.

Hörtensteiner, S., Kräutler, B., 2011. Chlorophyll breakdown in higher plants. Biochim. Biophys. Acta (BBA) - Bioenerg. 1807, 977-988. http://dx.doi.org/10.1007/ s000180050434.

Inagaki, M.N., Mori, M., Nachit, M.M., 2009. Effect of a strobilurin-class fungicide on water use in synthetic bread wheat genotypes grown under increasing water deficit conditions. Cereal Res. Commun. 37, 513-519. http://dx.doi.org/10.1556/CRC.37. 2009.4.4.

Irisarri, P., Binczycki, P., Errea, P., Martens, H.J., Pina, A., 2015. Oxidative stress associated with rootstock-scion interactions in pear/quince combinations during early stages of graft development. J. Plant Physiol. http://dx.doi.org/10.1016/j.jplph. 2014.10.015.

Ishikawa, S., Hare, M.C., Kettlewell, P.S., 2012. Effects of strobilurin fungicide programmes and fertilizer nitrogen rates on winter wheat: leaf area, dry matter yield and nitrogen yield. J. Agric. Sci. 150, 427-441. http://dx.doi.org/10.1017/ S0021859611000724.

Jørgensen, L.N., Olesen, J.E., 2002. Fungicide treatments affect yield and moisture content of grain and straw in winter wheat. Crop Prot. 21, 1023-1032. http://dx.doi.org/ 10.1016/S0261-2194(02)00086-8.

Jabs, T., Pfirrmann, J., Schäfer, S., Wu, Y., 2002. In: Anti-oxidative and anti-senescence effects of the strobilurin pyraclostrobin in plants: a new strategy to cope with environmental stress in cereals. The BCPC Conference: Pests and diseases, Volumes 1 and 2. Proceedings of an international conference held at the Brighton Hilton Metropole Hotel, Brighton, UK. pp. 941-946.

Jadoski, C.J., Rodrigues, J.D., Soratto, R.P., dos Santos, C.M., Ribeiro, E., 2015. Ação fisiológica da piraclostrobina na assimilação de $\mathrm{CO}_{2}$ e enzimas antioxidantes em plantas de feijão condicionado em diferentes tensões de água no solo. Irriga. 20, 319. http://dx.doi.org/10.15809/irriga.2015v20n2p319.

Joshi, J., Sharma, S., Guruprasad, K.N., 2014. Foliar application of pyraclostrobin fungicide enhances the growth, rhizobial-nodule formation and nitrogenase activity in soybean. Pestic. Biochem. Physiol. 114, 61-66. http://dx.doi.org/10.1016/j.pestbp. 2014.07.002.

Kar, M., Mishra, D., 1976. Catalase, peroxidase, and polyphenoloxidase activities during rice leaf senescence. Plant Physiol. 57, 315-319. https://doi.org/10.1104/pp.57.2. 315.
Kildea, S., Dunne, B., Mullins, E., Cooke, L.R., Mercer, P.C., O'Sullivan, E. 2010. Pyraclostrobin reduces germ tube growth of QoI-resistant Mycosphaerella graminicola pycnidiospores and the severity of septoria tritici blotch on winter wheat. Plant Pathol. 59, 1091-1098. http://dx.doi.org/10.1111/j.1365-3059.2010.02348.x.

Koehle, H., Grossmann, K., Jabs, T., Stierl, R., Gerhard, M., Kaiser, W., Glaab, J., Conrath, U., Seehaus, K., Herms, S., 2002. Physiological Effects of the Strobilurin Fungicide F 500 on Plants Modern Fungicides and Antifungal Compounds III. Mann GmbH \& Co. KG, Bonn, Germany, pp. 61-74.

Kozlowski, L.A., Simões, D.F.M., Souza, C.D., Tentro, M., 2009. Efeito fisiológico de estrobilurina F $500^{\circ}$ no crescimento e rendimento do feijoeiro. Rev. Acad. Ciên. Agr. Ambient. 7, 41-54.

Larcher, W., 2006. Ecofisiologia Vegetal. RiMa.

Lee, J.-M., Oda, M., 2010. Grafting of Herbaceous Vegetable and Ornamental Crops, Horticultural Reviews. John Wiley \& Sons, Inc., pp. 61-124. http://dx.doi.org/10. 1002/9780470650851.

Liu, J., Li, J., Su, X., Xia, Z., 2014. Grafting improves drought tolerance by regulating antioxidant enzyme activities and stress-responsive gene expression in tobacco. Environ. Exp. Bot. 107, 173-179. http://dx.doi.org/10.1016/j.envexpbot.2014.06. 012 .

Martínez-Ballesta, M.C., Alcaraz-López, C., Muries, B., Mota-Cadenas, C., Carvajal, M., 2010. Physiological aspects of rootstock-scion interactions. Sci. Hortic. 127, 112-118. http://dx.doi.org/10.1016/j.scienta.2010.08.002.

Mohammadi, A., Omid, M., 2010. Economical analysis and relation between energy inputs and yield of greenhouse cucumber production in Iran. Appl. Energy 87, 191-196. http://dx.doi.org/10.1016/j.apenergy.2009.07.021.

Nason, M.A., Farrar, J., Bartlett, D., 2007. Strobilurin fungicides induce changes in photosynthetic gas exchange that do not improve water use efficiency of plants grown under conditions of water stress. Pest Manag. Sci. 63, 1191-1200. http://dx. doi.org/10.1002/ps.1443.

Peixoto, P.H.P., Cambraia, J., Sant'Anna, R., Mosquim, P.R., Moreira, M.A., 1999. Aluminum effects on lipid peroxidation and on the activities of enzymes of oxidative metabolism in sorghum. Rev. Bras. Fisiol. Veg. 11, 137-143.

Rama Devi, S., Prasad, M.N.V., 1998. Copper toxicity in Ceratophyllum demersum L. (Coontail), a free floating macrophyte: response of antioxidant enzymes and antioxidants. Plant Sci. 138, 157-165. http://dx.doi.org/10.1016/S0168-9452(98) 00161-7.

Rouphael, Y., Schwarz, D., Krumbein, A., Colla, G., 2010. Impact of grafting on product quality of fruit vegetables. Sci. Hortic. 127, 172-179. http://dx.doi.org/10.1016/j. scienta.2010.09.001.

Ruske, R., Gooding, M., Jones, S., 2003. The effects of triazole and strobilurin fungicide programmes on nitrogen uptake, partitioning, remobilization and grain $\mathrm{N}$ accumulation in winter wheat cultivars. J. Agric. Sci. 140, 395-407. http://dx.doi.org/10. 1017/S0021859603003228.

Sarwat, M., Naqvi, A.R., Ahmad, P., Ashraf, M., Akram, N.A., 2013. Phytohormones and microRNAs as sensors and regulators of leaf senescence: assigning macro roles to small molecules. Biotechnol. Adv. 31, 1153-1171. http://dx.doi.org/10.1016/j. biotechadv.2013.02.003.

Sauter, H., Steglich, W., Anke, T., 1999. Strobilurins: evolution of a new class of active substances. Angew. Chem. Int. Ed. 38, 1328-1349. http://doi.org/10.1002/(SICI) 1521-3773(19990517)38:10<1328::AID-ANIE1328 > 3.0.CO;2-1.

Savvas, D., Colla, G., Rouphael, Y., Schwarz, D., 2010. Amelioration of heavy metal and nutrient stress in fruit vegetables by grafting. Sci. Hortic. 127, 156-161. http://dx. doi.org/10.1016/j.scienta.2010.09.011.

Schwarz, D., Rouphael, Y., Colla, G., Venema, J.H., 2010. Grafting as a tool to improve tolerance of vegetables to abiotic stresses: thermal stress, water stress and organic pollutants. Sci. Hortic. 127, 162-171. http://dx.doi.org/10.1016/j.scienta.2010.09. 016.

Semar, M., Strobel, D., Strathmann, S., Groeger, U., 2011. Xemium - the basf fungicide innovation. In: Dehne, H.W., Deising, H.B., Gisi, U., Kuck, K.H., Russel, P.E., Lyr, H. (Eds.), Modern Fungicides and Antifungal Compounds VI: Proceedings of the 16th International Reinhardsbrunn Symposium, April 25-29, 2010, Braunschweig, Germany. DPG Selbstverlag, Braunschweig, pp. 63-68.

Soares, L.H., Fagan, E.B., Casaroli, D., Andrade, D.M., Soares, A.L., Martins, K.V., Rocha, F.J., 2011. Aplicação de diferentrs estrobilurinas na cultura da soja. Rev. FZVA 18.

Stammler, G., Speakman, J., 2006. Microtiter method to test the sensitivity of botrytis cinerea to boscalid. J. Phytopathol. 154, 508-510. http://dx.doi.org/10.1111/j. 1439-0434.2006.01139.x.

Stammler, G., Benzinger, G., Speakman, J., 2007. A rapid and reliable method for monitoring the sensitivity of sclerotinia sclerotiorum to boscalid. J. Phytopathol. 155, 746-748. http://dx.doi.org/10.1111/j.1439-0434.2007.01294.x.

Stammler, G., Brix, H.D., Nave, B., Gold, R., Schoefl, U., 2008. Studies on the biological performance of boscalid and its mode of action. In: Dehne, H.W., Deising, H.B., Gisi, U., Kuck, K.H., Russel, P.E., Lyr, H. (Eds.), Modern Fungicides and Antifungal Compounds V: Proceedings of the 15th International Reinhardsbrunn Symposium, May 06-10, 2007, Braunschweig, Germany. DPG Selbstverlag, Braunschweig, pp. 45-51.

Streeter, J.G., Bosler, M.E., 1972. Comparison of in vitro and in vivo assays for nitrate reductase in soybean leaves. Plant Physiol. 49 (3), 448. https://doi.org/10.1104/pp. 49.3.448.

Teisseire, H., Guy, V., 2000. Copper-induced changes in antioxidant enzymes activities in fronds of duckweed (Lemna minor). Plant Sci. 153, 65-72. http://dx.doi.org/10. 1016/S0168-9452(99)00257-5.

Venancio, W.S., Rodrigues, M.A.T., Begliomini, E., Souza, N.L., 2003. Physiological effects of strobilurin fungicides on plants. Ciências Exatas e da Terra. Ciências Agrárias e Engenharias 9, 59-68.

Venema, J.H., Dijk, B.E., Bax, J.M., van Hasselt, P.R., Elzenga, J.T.M., 2008. Grafting 
tomato (Solanum lycopersicum) onto the rootstock of a high-altitude accession of Solanum habrochaites improves suboptimal-temperature tolerance. Environ. Exp. Bot. 63, 359-367. http://dx.doi.org/10.1016/j.envexpbot.2007.12.015.

Ypema, H.L., Gold, R.E., 1999. Kresoxim-methyl: modification of a naturally occurring compound to produce a new fungicide. Plant Dis. 83, 4-19. http://dx.doi.org/10.
1094/PDIS.1999.83.1.4.

Zhang, Y.-J., Zhang, X., Chen, C.-J., Zhou, M.-G., Wang, H.-C., 2010. Effects of fungicides JS399-19, azoxystrobin, tebuconazloe, and carbendazim on the physiological and biochemical indices and grain yield of winter wheat. Pestic. Biochem. Physiol. 98, 151-157. http://dx.doi.org/10.1016/j.pestbp.2010.04.007. 